\title{
Hydropriming as inducer of salinity tolerance in sunflower seeds
}

\author{
Janete R. Matias ${ }^{1}$, Salvador B. Torres ${ }^{1}$, Caio C. P. Leal ${ }^{1}$, Moadir de S. Leite ${ }^{1}$ \& Sara M. C. Carvalho ${ }^{1}$ \\ ${ }^{1}$ Universidade Federal Rural do Semi-Árido/Centro de Ciências Agrárias/Departamento de Ciências Agronômicas e Florestais. Mossoró, RN. \\ E-mail: janete07@hotmail.com - ORCID: 0000-0001-9828-9866; sbtorres@ufersa.edu.br - ORCID: 0000-0003-0668-3327 (Corresponding author); \\ caioleal3@hotmail.com - ORCID: 0000-0001-7745-1836; moadir@outlook.com - ORCID: 0000-0003-0432-0522; saramonaliza@ufersa.edu.br \\ - ORCID: 0000-0001-7827-4472
}

\section{Key words: \\ Helianthus annuus \\ Asteraceae \\ physiological conditioning \\ abiotic stress \\ electrical conductivity}

\begin{abstract}
A B S T R A C T
Sunflower is a species with multiple potentialities and its yield can be affected by the presence of soluble salts in the soil, which is common in arid, semi-arid and irrigated regions. The objective of this study was to evaluate the effect of hydropriming as inducer of salinity tolerance in seeds and seedlings of sunflower, hybrid MG305CP. The germination tests were set with four replicates of 50 seeds per treatment, maintained in germinator at $30^{\circ} \mathrm{C}$ for ten days. To simulate salinity, sodium chloride diluted in distilled water was used at electrical conductivities of 0 (control), 4, 8, 12 and $16 \mathrm{dS} \mathrm{m}^{-1}$. On the tenth day, the number of normal seedlings was counted and the length and dry matter of shoots and roots were determined. Seedling fresh matter was used to determine the contents of total chlorophyll, total soluble sugars and proline. The experimental design was completely randomized, in a $2 \times 5$ factorial scheme (with and without hydropriming and five levels of salinity). Hydroprimed sunflower seeds showed greater vigor expression, with higher number of normal seedlings and faster germination.
\end{abstract}

\section{Palavras-chave:}

Helianthus annuus

Asteraceae condicionamento fisiológico estresse abiótico condutividade elétrica

\section{Hidrocondicionamento como indutor de tolerância à salinidade em sementes de girassol}

\begin{abstract}
R E S U M O
O girassol é uma espécie com múltiplas potencialidades, cuja produtividade pode ser afetada pela presença de sais solúveis no solo, fato comum em regiões áridas, semiáridas e irrigadas. Nesta pesquisa, objetivou-se avaliar o efeito do hidrocondicionamento como indutor de tolerância à salinidade em sementes e plântulas de girassol, híbrido MG305CP. Os testes de germinação foram instalados com quatro repetiçães de 50 sementes por tratamento, sendo mantidos em germinador a $30^{\circ} \mathrm{C}$ por dez dias. Para simular a salinidade, utilizou-se cloreto de sódio diluído em água destilada nas condutividades elétricas de 0 (controle); 4; 8; 12 e $16 \mathrm{dS} \mathrm{m}^{-1}$. No décimo dia, computou-se o número de plântulas normais, comprimento e massa seca de parte aérea e raiz. A partir da matéria fresca de plântulas foi determinado o teor de clorofila total, açúcar solúveis totais e prolina. O delineamento experimental foi o inteiramente casualizado, em esquema fatorial 2 x 5 (com e sem hidrocondicionamento e cinco níveis de salinidade). As sementes de girassol hidrocondicionadas apresentaram maior expressão de vigor com maior número de plântulas normais e germinação mais rápida.
\end{abstract}




\section{INTRODUCTION}

Sunflower (Helianthus annuus L.) is a crop used for various purposes, including animal feed, extraction of oil for human consumption or as raw material for biodiesel and pharmaceutical industry (Leite et al., 2005). Among the factors that interfere with its production, the presence of soluble salts in the soil solution stands out for causing direct or indirect damages, with higher influence in the initial stages of crop development (Garcia et al., 2010).

The stress caused by salinity reduces the agricultural yield of many species, because it inhibits plant growth through actions of the water deficit and osmotic effects, besides the ionic excess or specific damages of the salt (Sobhanian et al., 2010). Under these conditions, the plant invest in shoot development and reduces its root system (Silva et al., 2016), and increases the concentration of proline and carbohydrates (Esteves \& Suzuki, 2008).

Among the methods that favor salinity tolerance, seed physiological conditioning stands out for allowing controlled hydration (Marcos Filho, 2015), which promotes the activation of metabolic processes, normally triggered during the initial stage of germination (pre-germination metabolism), but not reaching radicle protrusion (beginning of stage III) (Bewley et al., 2013). The practical results of this technique are the increase in germination rate, germination speed and seedling germination, as well as uniformity (Singh et al., 2015). These factors may result in better crop establishment under adverse conditions and, therefore, high levels of yield (Bewley et al., 2013).

Among the techniques used for physiological conditioning, halopriming refers to the soaking of seeds in solution of inorganic salts such as $\mathrm{NaCl}, \mathrm{KNO}_{3}, \mathrm{CaCl}_{2}$ and $\mathrm{CaSO}_{4}$, osmopriming refers to the soaking of seeds for a specific period in polyethylene glycol (PEG) solution and hydropriming refers to the soaking of seeds in water before sowing, which may or may not be followed by seed drying. These methods play an important role in the germination of different crop species, even under saline conditions (Singh et al., 2015). Hydropriming stands out for its practicality and requires low investments in reagents, compared with the other methods, besides avoiding interference of substances that are undesirable or harmful to the seeds during soaking.

Since salinity limits the performance of the species, studies aiming at attenuating this type of stress are of great importance for seeds to be able to establish under such conditions, normally by developing mechanisms of resistance and, therefore, conclude the process of germination and seedling formation satisfactorily (Singh et al., 2015). This study aimed to evaluate the effect of hydropriming as inducer of salinity tolerance in seeds and seedlings of sunflower, hybrid MG305CP.

\section{Material ANd Methods}

The experiment was carried out at the Laboratory of Seed Analysis of the Center of Agricultural Sciences of the Federal Rural University of the Semi-Arid Region (UFERSA), Mossoró-RN, Brazil (5¹2’ 14” S; 37 19’ 26” W; 23 m), using seeds of sunflower, hybrid MG305CP.
Initially, the seeds were subjected to the soaking curve, using four replicates of 20 seeds each, sown on paper towel (Germitest ${ }^{\circ}$ ) in water volume equivalent to 2.5 times its dry weight, at $20{ }^{\circ} \mathrm{C}$ (Neves, 2014). The seeds were weighed at the times of $1,2,3,4,6,8,10,12,14,16,20,24,28$ and $32 \mathrm{~h}$ of soaking, in which $50 \%$ of the seeds showed radicle longer than $2 \mathrm{~mm}$.

For the hydropriming, the seeds were subjected to soaking in the same substrate and same amount of water used to determine the soaking curve for $20 \mathrm{~h}$. Subsequently, the seeds were removed from the substrate and subjected to drying on paper towel for $72 \mathrm{~h}$ at room temperature of $30{ }^{\circ} \mathrm{C}$ (Neves, 2014). Soaking percentage was calculated based on the initial weight of the seeds (Brasil, 2009).

Salt stress was simulated using solutions of sodium chloride $(\mathrm{NaCl})$, in distilled water, with the following electrical

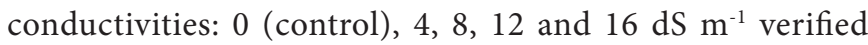
using a digital conductivity meter Model Tec-4MP, properly calibrated. At the level zero, distilled water was used to moisten the substrate.

The germination test was carried out in germinator, at $30^{\circ} \mathrm{C}$, with four replicates of 50 seeds per treatment (Brasil, 2009). As germination started, the number of germinated seeds was daily counted until the tenth day, considering as germinated the seeds that produced the radicle $(\geq 2 \mathrm{~mm})$. These data were used to determine the germination speed index, calculated according to the formula proposed by Maguire (1962).

Shoot length and root length, as well as dry matter, were evaluated along with the germination test, at 10 days, using 10 normal seedlings per replicate for each treatment. Shoot and root length were measured using a ruler graduated in millimeters and the results were expressed in centimeter per seedling. For dry matter, seedlings were placed in paper bags, maintained in an oven at $60{ }^{\circ} \mathrm{C}$ until constant weight, and weighed on a scale $(0.001$-g precision). The results were expressed in g seedling $^{-1}$.

After the germination test, the seedlings were collected for later biochemical quantification. Chlorophyll was determined according to the methodology described by Arnon (1949), and the results were expressed in mg of chlorophyll per gram of fresh weight. Total soluble sugars were quantified by the method of Yemm \& Willis (1954), whereas free proline was quantified by the acid ninhydrin method (Bates et al., 1973).

The experimental design was completely randomized, in $2 \times 5$ factorial scheme (with and without hydropriming and five levels of salinity). The results were subjected to analysis of variance and regression. Means were compared by Tukey test at 0.05 probability test using the program SISVAR for Windows, version 4.1 (Ferreira, 2011).

\section{Results AND Discussion}

Soaking of sunflower seeds showed a triphasic model, with duration of $24 \mathrm{~h}$ until reaching the stage III; and, after $32 \mathrm{~h}$, $50 \%$ of the seeds exhibited radicle longer than $2 \mathrm{~mm}$. Beginning of phase I was observed in the first hours, with high speed of water absorption and dry matter accumulation. Water soaking in phase II, between 14 and $24 \mathrm{~h}$, was slower than in phase I (Figure 1). 


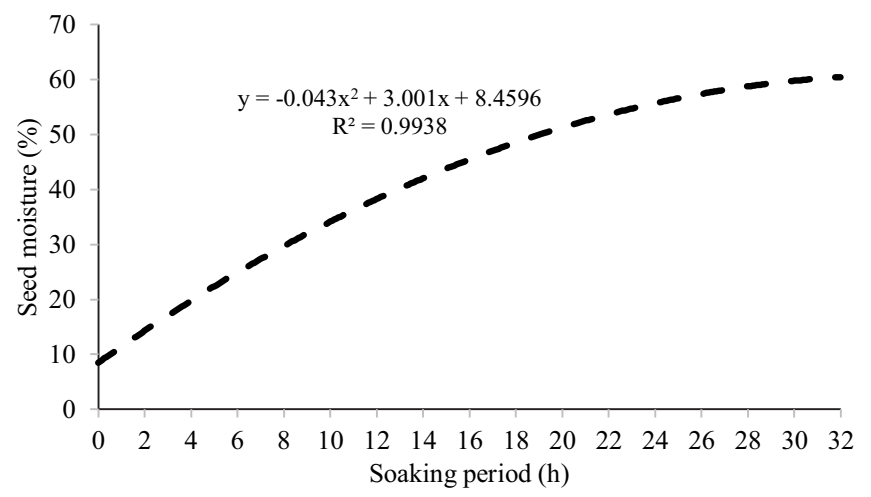

Figure 1. Soaking curve of sunflower seeds

Between hydropriming and salinity levels, there was significant interaction at 0.01 probability level $(\mathrm{p}<0.01)$ for germination characteristics, normal seedlings, shoot length (SL), root length (RL), shoot dry matter (SDM) and root dry matter (RDM). On the other hand, germination speed index (GSI) showed significant difference only between the treatments with and without hydropriming, not showing difference between salinity levels.

Damages caused by salinity may be related to the difficulty to absorb water and the consequent damage to germination and other phases of the seedling development process. In addition, morphological alterations and physiological and biochemical processes are normally affected (Garcia et al., 2010).

Germination occurred until the highest salinity tested, equivalent to electrical conductivity of $16 \mathrm{dS} \mathrm{m} \mathrm{m}^{-1}$, with and without hydropriming (Figure 2A). In non-salinized substrate $\left(0 \mathrm{dS} \mathrm{\textrm {m } ^ { - 1 }}\right)$, there was maximum germination in hydroprimed seeds, intensified by the vigor achieved, which suggests a possible osmotic adjustment by the seeds, i.e., mechanisms of repair at subcellular level possibly activated, allowing the occurrence of initial metabolic steps of the germination process, and expressing higher seed germination.

In saline environment, there was linear reduction in the number of normal seedlings, and the effects were accentuated as the saline concentration increased, until there were only abnormal seedlings (Figure $2 \mathrm{~B}$ ). In the physiological conditioning using PEG 6000 in seeds of Sorghum bicolor, as observed in the present study, hydropriming allowed the seeds to express higher vigor, especially under high salinity conditions (200 mM) (Oliveira et al., 2011).

Slow and non-uniform germination are consequences of salinity, and tolerance to salinity will depend on the species (Andréo-Souza et al., 2010). For seeds of Brassica oleracea. var. italica, and Jatropha curcas, germination speed decreased in saline environment (Andréo-Souza et al., 2010; Lopes et al., 2014). However, for sunflower the increment in saline concentration did not cause significant difference in GSI, differing only for seeds with and without hydropriming (Figure 2C).

Based on the GSI, sunflower seeds showed positive response to hydropriming (Figure 2C). Possibly, because hydroprimed seeds had been previously subjected to soaking and placed back into contact with water, it was no longer necessary to repeat the processes already occurred in the hydration and that allowed the reorganization and activation of cellular events that were inactive due to the desiccation (Bewley et al., 2013). Thus, seeds
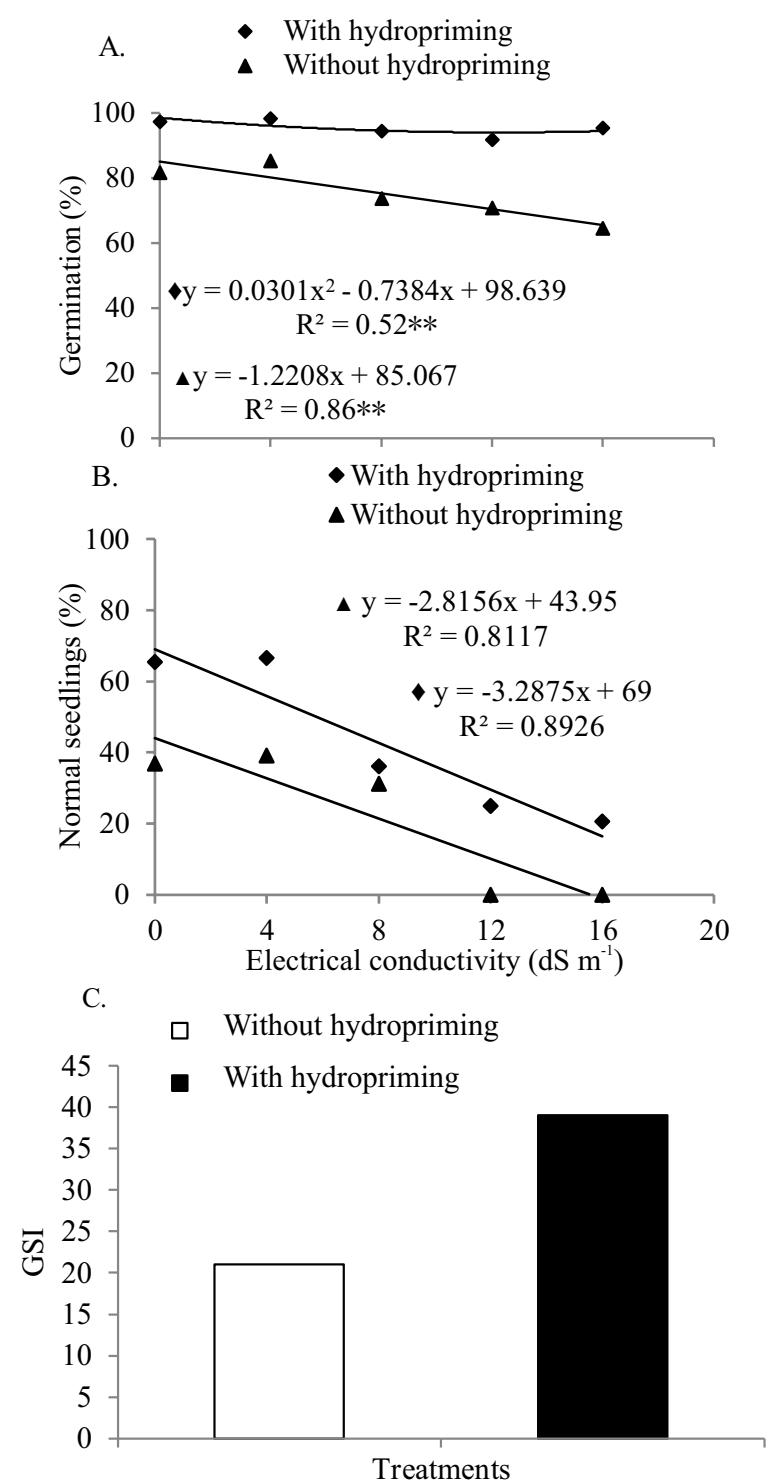

Figure 2. Germination (A), normal seedlings (B) and germination speed index (GSI, C) of sunflower seeds, hybrid MGP305CP, with and without hydropriming at different salinity levels

were physiologically closer to the beginning of the soaking phase III and, consequently, to radicle protrusion, showing higher values of germination speed.

Plant growth and survival under saline conditions depend upon adaptation to high concentrations of salts. Although a reduction in shoot length is expected at high salinity levels (Wu et al., 2015), the point at which such reduction occurs is variable. Sunflower plants showed more accentuated reduction in the shoots from $8 \mathrm{dS} \mathrm{m} \mathrm{m}^{-1}$ on (Figure $3 \mathrm{~A}$ ), thus exhibiting resistance until this point. This may have occurred as a survival strategy, investing more energy in shoot growth, since this structure is responsible for photosynthesis and must grow above soil surface before endosperm reserves become completely depleted (Silva et al., 2016).

Root length decreased as salinity increased (Figure 3B), as also occurs in Zea mays (Silva et al., 2016) and Phaseolus vulgaris (Dalchiavon et al., 2016), species that, as sunflower, have lower investment in the root system. With the hydropriming, root dry matter showed a quadratic behavior as electrical conductivity increased to up to $12 \mathrm{dS} \mathrm{m}^{-1}$ (Figure 3D). 
Seeds without hydropriming, when subjected to increment in electrical conductivity, showed linear reduction in shoot dry matter (Figure 3C), whereas the dry matter was higher with the hydropriming, remaining virtually constant up to the highest electrical conductivity studied. This fact is related to the amount of water available to the seeds, and the increase in salt concentration tends to reduce such availability during germination and affects cell division and elongation, compromising the mobilization of reserves that are essential to the germination process, which leads to reduction in seedling length and lower dry matter accumulation (Kerbauy, 2004).

Total chlorophyll content (Figure 4A) decreased to 6.56 until EC of approximately $5.7 \mathrm{dS} \mathrm{m}^{-1}$ and, subsequently, increased to 29.46 at EC of $16 \mathrm{dS} \mathrm{m}^{-1}$ in seedlings without hydropriming. This factor may have been caused by the imbalances in physiological and biochemical activities due to the excess of salts above the tolerated levels (Munns \& Tester, 2008). However, with seed hydropriming, possibly for promoting resistance to salinity, the response was increasing, with a slight decrease at EC of $16 \mathrm{dS} \mathrm{m}^{-1}$, demonstrating that this is the maximum limit of tolerance to salinity (Figure 4A).

Because of the salinity, the photosynthetic capacity tends to decrease, which can also be attributed to the reduction in the contents of photosynthetic pigments. In plants that are sensitive to salinity, chlorophyll contents decrease, and there is an increase in salt-tolerant plants (Jamil et al., 2007). However, the increment in total chlorophyll content under higher stress, from $8 \mathrm{dS} \mathrm{m}^{-1}$ on, in seedlings with and without hydropriming, may be a response of acclimation to the stress caused by sodium chloride, adopted in the attempt to save energy and, consequently, capture less light energy, thus avoiding possible photooxidative stresses (Tabot \& Adams, 2013).

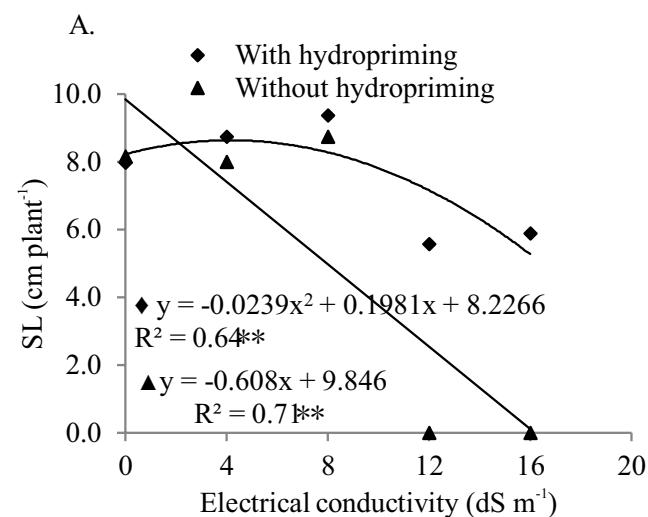

C

- With hydropriming

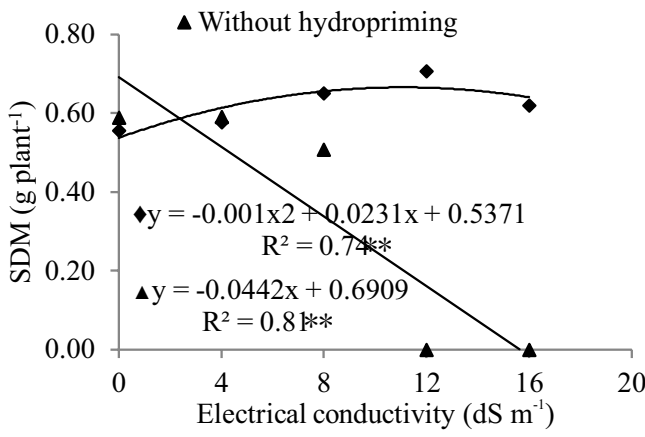

Salinity can interfere not only with germination, but also with biochemical processes, and can trigger alterations in the concentration of proline and carbohydrates, synthesis of amino acids, or even alterations in the absorption of essential nutrients (Esteves \& Suzuki, 2008).

Total soluble sugars in plants under saline stress conditions tends to increase due to the capacity of some species to adjust osmotically under adverse conditions (Silva et al., 2010). These authors observed in J. curcas L. accumulation of soluble sugars as its main osmolytes, occurring an osmotic adjustment in response to the drought, indirectly related to salinity. Contents of total soluble sugars in sunflower seedlings originated from hydroprimed seeds were higher compared with those from seeds without hydropriming (Figure 4B). This accumulation may be related to the lower use of this solute to protect the photosynthetic apparatus from damages, at higher salinity levels (Wu et al., 2015).

For performing functions of protection of the plasma membrane, proline acts as antioxidant and in the maintenance of $\mathrm{C}$ and $\mathrm{N}$ contents in plants that are recovering from stress (Gupta \& Huang, 2014). Under this condition, the seedling produces this amino acid to osmotically adjust the cells. Hydroprimed sunflower seedlings did not accumulate proline (Figure 4C), suggesting that this technique attenuated the saline stress; consequently, proline had a protecting effect (Munns \& Tester, 2008). Similar behavior was observed in Vigna unguiculata (Praxedes et al., 2009), indicating that hydropriming of seeds can be a mechanism of protection against the excess of salts.

Proline accumulated as salinity increased in seedlings grown from seeds without hydropriming (Figure 4C), and the opposite response occurred for hydroprimed seeds. Thus, the
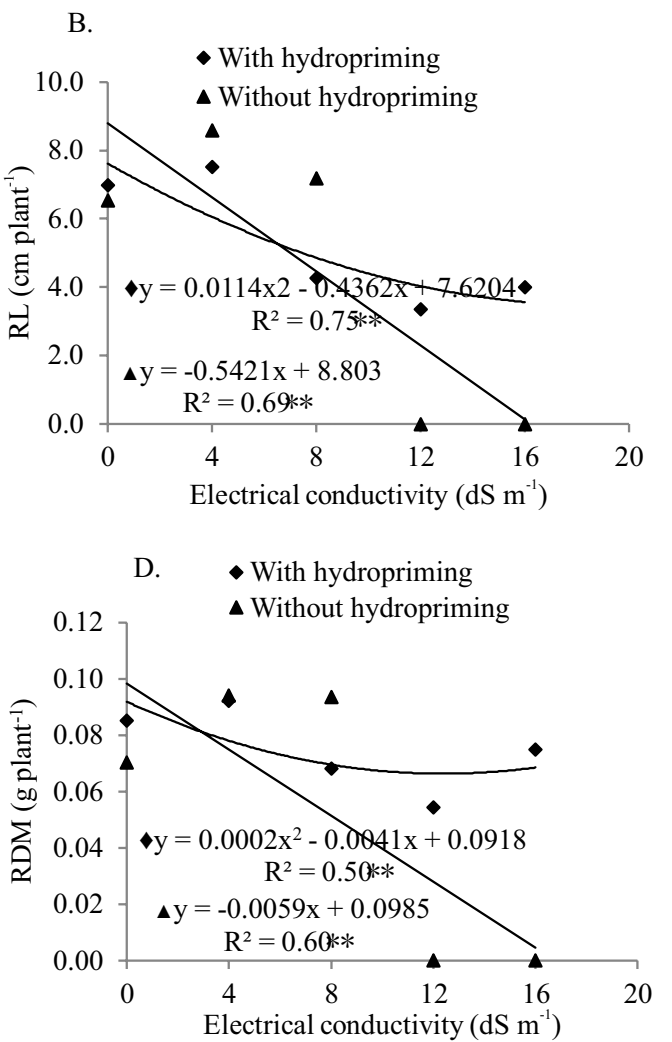

Figure 3. Shoot length (SL, A), root length (RL, B), shoot dry matter (SDM, C) and root dry matter (RDM, D) of sunflower seedlings, hybrid MGP305, with and without hydropriming, at different salinity levels 


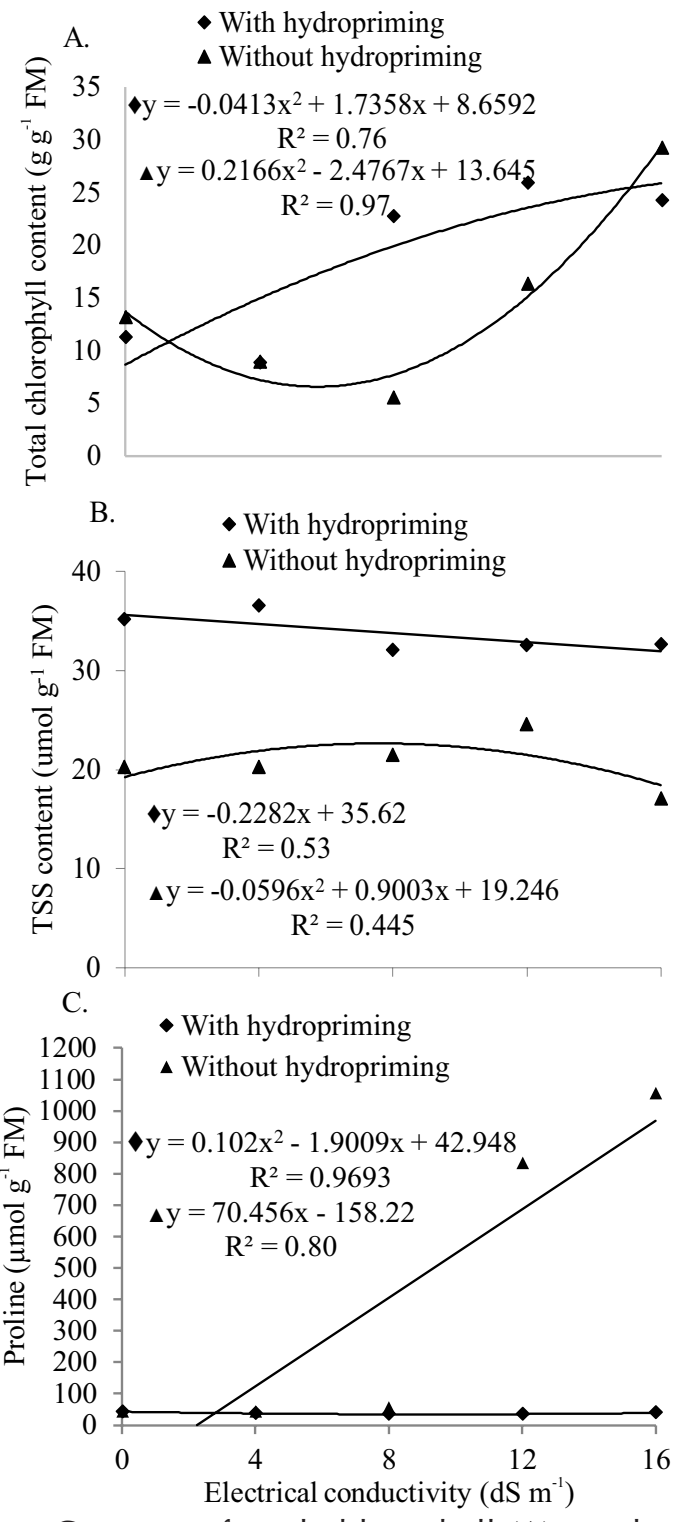

Figure 4. Contents of total chlorophyll (A), total soluble sugars (TSS, B) and proline (C) in sunflower seedlings, hybrid MGP305CP, with and without hydropriming, at different salinity levels

proline content can be considered as an efficient biochemical and physiological indicator of the effect of salinity on sunflower seeds. Therefore, proline performed the function of key osmolyte in the osmotic adjustment of plants under abiotic stress for osmoprotective functions (Giannakoula et al., 2008). This mechanism is established through the accumulation, in the vacuole or cytosol, of compatible solutes such as proline, which contribute to maintaining water balance and preserving the integrity of proteins, enzymes and cell membranes (Gupta \& Huang, 2014).

\section{Conclusions}

1. Hydropriming in sunflower seeds attenuated the stressful effect caused by sodium chloride, in initial stages of seedling development.

2. Hydroprimed sunflower seeds showed greater expression of vigor, with higher number of normal seedlings and faster germination.

\section{Literature Cited}

Andréo-Souza, Y.; Pereira, A. L.; Silva, F. F. S. da; Ribeiro-Reis, R. C.; Evangelista, M. R. V.; Castro, R. D. de; Dantas, B. F. Efeito da salinidade na germinação de sementes e no crescimento inicial de mudas de pinhão-manso. Revista Brasileira de Sementes, v.32, p.83-92, 2010. https://doi.org/10.1590/S0101-31222010000200010

Arnon, D. J. Cooper enzymes in isolated chloroplast: Polyphenoloxidase in Beta vulgaris. Plant Physiology, v.24, p.1-15, 1949. https://doi. org/10.1104/pp.24.1.1

Bates, L. S.; Waldren, R. P.; Teare, I. D. Rapid determination of free proline for water-stress studies. Plant and Soil, v.39, p.205-207, 1973. https:// doi.org/10.1007/BF00018060

Bewley, J. D.; Bradford, K. J.; Hilhorst, H. W. M.; Nonogaki, H. Seeds, physiology of development, germination and dormancy. 3.ed. New York: Springer, 2013. 392p.

Brasil. Ministério da Agricultura, Pecuária e Abastecimento. Secretaria de Defesa Agropecuária. Regras para análise de sementes. Brasília: MAPA-ACS, 2009. 395p.

Dalchiavon, F. C.; Neves, G.; Haga, K. I. Efeito de estresse salino em sementes de Phaseolus vulgaris. Revista de Ciências Agrárias, v.39, p.404-412, 2016. http://dx.doi.org/10.19084/RCA15161

Esteves, B. S.; Suzuki, M. S. Efeito da salinidade sobre as plantas. Revista Oecologia Brasiliensis, v.12, p.662-679, 2008. https://doi.org/10.4257/ oeco.2008.1204.06

Ferreira, D. F. Sisvar: A computer statistical analysis system. Ciência e Agrotecnologia, v.35, p.1039-1042, 2011. https://doi.org/10.1590/ S1413-70542011000600001

Garcia, G. O.; Nazário, A. A.; Moraes, W. B.; Gonçalves, I. Z.; Madalão, J. C. Respostas de genótipos de feijoeiro à salinidade. Engenharia na Agricultura, v.18, p.330-338, 2010. https://doi.org/10.13083/14143984.v18n04a07

Giannakoula, A.; Moustakas, M.; Mylona, P.; Papadakis, I.; Yupsanis, T. Aluminum tolerance in maize is correlated with increased levels of mineral nutrients, carbohydrates and proline, and decreased levels of lipid peroxidation and $\mathrm{Al}$ accumulation. Journal of Plant Physiology, v.165, p.385-396, 2008. https://doi.org/10.1016/j.jplph.2007.01.014

Gupta, B.; Huang, B. Mechanism of salinity tolerance in plants: Physiological, biochemical, and molecular characterization. International Journal of Genomics, v.2014, p.1-18, 2014. https://doi. org/10.1155/2014/701596

Jamil, M.; Rehman, S. ur; Lec, K. J.; Kim, J. M.; Kim, H.-S.; Rha, E. S. Salinity reduced growth PS2 photochemistry and chlorophyll content in radish. Scientia Agrícola, v.64, p.111-118, 2007. https:// doi.org/10.1590/S0103-90162007000200002

Kerbauy, G. B. Fisiologia vegetal. Rio de Janeiro: Guanabara Koogan, 2004. 452p.

Leite, R. M. V. B.; Brighenti, A. M.; Castro, C. Girassol no Brasil. Londrina: Embrapa Soja, 2005. 641p.

Lopes, K. P.; Nascimento, M. das G. R. do; Barbosa, R. C. A.; Costa, C. C. Salinidade na qualidade fisiológica em sementes de Brassicas oleracea L. var. itálica. Semina: Ciências Agrárias, v.35, p.2251-2259, 2014. https://doi.org/10.5433/1679-0359.2014v35n5p2251

Maguire, J. D. Speed of germination-aid in selection and evaluation for seedling emergence and vigor. Crop Science, v.2, p.176-177, 1962. https://doi.org/10.2135/cropsci1962.0011183X000200020033x

Marcos Filho, J. Fisiologia de sementes de plantas cultivadas. Piracicaba: FEALQ, 2015. 659p.

Munns, R.; Tester, M. Mechanisms of salinity tolerance. Annual Review of Plant Biology, v.12, p.662-679, 2008. https://doi. org/10.1146/annurev.arplant.59.032607.092911 
Neves, M. B. Priming de sementes de girassol relacionado à conservação das sementes e ao desenvolvimento das plantas. Piracicaba: USP, 2014. 182p. Tese Doutorado

Oliveira, A. B. de; Alencar, N. L. M.; Prisco, J. T.; Gomes Filho, E. Accumulation of organic and inorganic solutes in $\mathrm{NaCl}$-stressed sorghum seedlings from aged and primed seeds. Scientia Agricola, v.68, p.632-637, 2011. https://doi.org/10.1590/S010390162011000600004

Praxedes, S. C.; Ferreira, T. M.; Gomes-Filho, E. Acúmulo de prolina e aminoácidos em cultivares de feijão-caupi com tolerância diferencial à salinidade. Revista Caatinga, v.22, p.211-214, 2009.

Silva, E. N.; Ferreira-Silva, S. L.; Viégas, R. A.; Silveira, J. G. The role of organic and inorganic solutes in the osmotic adjustment of drought-stressed Jatropha curcas plants. Environmental and Experimental Botany, v.69, p.279-85, 2010. https://doi. org/10.1016/j.envexpbot.2010.05.001

Silva, R. C. da; Grzybowski, C. R. de S.; Panobianco, M. Vigor de sementes de milho: Influência no desenvolvimento de plântulas em condições de estresse salino. Revista Ciência Agronômica, v.47, p.491-499, 2016. http://dx.doi.org/10.5935/1806-6690.20160059
Singh, H.; Jassal, R. K.; Kang, J. S.; Sandhu, S. S.; Kang, H.; Grewal, $\mathrm{K}$. Seed priming techniques in field crops-A review. Agricultural Review, v.36, p.251-264, 2015. https://doi.org/10.18805/ ag.v36i4.6662

Sobhanian, H.; Razavizadeh, R., Nanjo, Y.; Ehsanpour, A. A.; Jazii, F. R.; Motamed, N.; Komatsu, S. Proteome analysis of soybean leaves, hypocotyls and roots under salt stress. Proteome Science, v.8, p.1-15, 2010. https://doi.org/10.1186/1477-5956-8-19

Tabot, P. T.; Adams, J. B. Early responses of Bassia diffusa (Thunb.) Kuntze to submergence for different salinity treatments. South African Journal of Botany, v.84, p. 19-29, 2013. https://doi. org/10.1016/j.sajb.2012.10.002

Wu, G. Q.; Jiao, Q.; Shui, Q. Z. Effect of salinity on seed germination, seedling growth, and inorganic and organic solutes accumulation in sunflower (Helianthus annuus L.). Plant, Soil and Environment, v.61, p.220-226, 2015. https://doi.org/10.17221/22/2015-pse

Yemm, E. W.; Willis, A. J. The estimation of carbohydrates in plants extracts by antrone. Biochemical Journal, v.57, p.508-514, 1954. https://doi.org/10.1042/bj0570508 